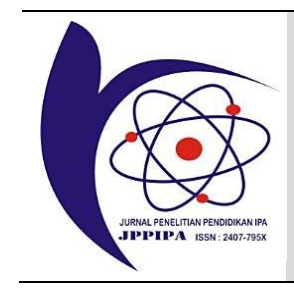

\title{
Effectiveness of Problem-based Learning Model Devices with Multiple Intelligences Approach to Improve Learners' Physics Problem-Solving Skills
}

\author{
Fatara Ananda Suwandi ${ }^{*}$, Hairunnisyah Sahidu ${ }^{1}$, I Wayan Gunada ${ }^{1}$ \\ ${ }^{1}$ Physics Education Study Program, FKIP, University of Mataram, Mataram, Lombok, West Nusa Tenggara, Indonesia.
}

\section{DOI: $\underline{\text { 10.29303/jppipa.v7iSpecialIssue.1064 }}$}

\section{Article Info}

Received: October 27th, 2021

Revised: December 7th, 2021

Accepted: December 11th, 2021

\begin{abstract}
This research aims to develop problem-based learning model learning tools with multiple intelligences approaches to improve the effective physics problem-solving skills of learners. This research is research and development with 4D models defined, designed, developed, and disseminated. The products developed in the form of syllabus, lesson plan, student worksheet, and instrument tests of learners' problem-solving and logicalmathematical skills. The validity of the product was assessed by six validators, namely three lecturers and three practitioner teachers with a Likert scale analysis. After the validity test, the learning device was conducted a limited trial that aims to measure the effectiveness of learning devices to get $\mathrm{N}$-gain test scores through questionnaires about the ability to solve problems and mathematical logic of learners and efficiency determined from the response of teachers and learners. The results of the study based on assessments from validators showed the overall device averaged above 3.27 with excellent categories. Then the average result of the $\mathrm{N}$-gain test obtained a value of 0.69 with a moderate category. Based on the results of the analysis of the response of learners to the module showed positive criteria with the acquisition of $66.7 \%$. These results can be concluded that the developed product is effectively used in learning.
\end{abstract}

Keywords: Effectiveness of devices; problem-based learning models; multiple intelligences; problem-solving capabilities.

Citation: Suwandi, A.F., Sahidu, H., \& Gunada, I. W. (2021). Effectiveness of Problem-based Learning Model Devices with Multiple Intelligences Approach to Improve Learners' Physics Problem-Solving Skills. Jurnal Penelitian Pendidikan IPA, 7(SpecialIssue), 238-243. https://doi.org/10.29303/jppipa.v7iSpecialIssue.1064

\section{Introduction}

When the government announced the first case of corona virus (Covid-19) disease in March 2019 in March 2020, Indonesia then faced a pandemic. Almost all sectors of life are affected, including the education sector. Therefore, teachers as educators must be able to find more effective learning strategies while still prioritizing the 2013 curriculum so as not to inhibit the spirit of student learning in the pandemic period (Asmuni, 2020).
Effectiveness is a very important factor in the lesson because it determines the success rate of a learning model used. Learning is said to be effective if the teaching and learning process goes well in accordance with learning goals and learning outcomes. Therefore, to harmonize a good learning process requires the right role of teachers in carrying out the learning process such as the selection of methods, media and how to evaluate learners. In addition, learning must be able to improve high-level thinking skills, especially problem-solving skills, in order to improve the quality of graduates.

\footnotetext{
*Email: nadafatara@gmail.com
} 
Problem-solving ability is a student's basic ability to use high-level reasoning and thinking to find the correct solution to the problems raised by the learning material. The weak ability of students to solve their own problems identifies the learning difficulties faced by students. Two factors cause student learning difficulties, namely internal factors, and external factors. From internal factors, learning difficulties are possible due to neurological disorders. The external factors that affect student learning difficulties include wrong learning strategies, classroom management that does not generate learning motivation, and inappropriate reinforcement (Kamsari \& Winarso, 2018). Where students' problem-solving skills are expected to develop (Venisari, et al., 2017). Therefore, a learning model is needed that will hone students' problem-solving skills by providing opportunities for students to play an active role in learning. One learning model that can be used is the problem-based learning model.

Problem Based Learning model is a learning model that is based on many problems that require authentic investigation, namely, an investigation that requires real solutions to real problems (Gunada, et al., 2015; Ramdoniati, et al., 2019). Model problem-based learning has a characteristic that is learning based on authentic problems (Wulandari \& Shofiyah, 2018). Each student tries to think critically, analyze, find information to solve problems so that all students in the group actively collect information from various sources to solve existing problems. One of the steps in problem-based learning is that students actively conduct studies independently by searching from various sources (Lestari, et al., 2015).

The advantages of this problem-based learning model can help students understand problems in everyday life during the learning process and take responsibility for their own learning (Pitriah, et al., 2018). In line with Hardiyanto, et al. (2015), when teachers want students to be able to analyze and apply known knowledge in new situations, and hope students can solve problems independently, then it is suitable to develop problem-based learning. This model is a model that can facilitate problem-solving skills (Wahyuni, et al., 2020). Problem-based learning not only assists students in acquiring knowledge, but also develops their problem-solving skills, critical and creative thinking, improves the effectiveness of their communication, cooperative study, and selfevaluation skills, and enables them to adapt (Selçuk \& Çalişkan, 2010).

While the majority of physics students agree that they can apply skills in solving problems (Sulaiman, 2010). Problems used in the learning model problembased is a real problem that occurs in the environment
(Supriadi, et al., 2020). Problem-based learning becomes a method that has various benefits such as determining problems, hypothesizing, getting information, and developing problem-solving skills (Celik, et al., 2011). This is closely related to compound intelligence.

The method of double intelligence is defined as double intelligence that solves problems faced in life. Compound intelligence theory explains that every child has compound intelligence, among others: language, logic, music, vision or space, kinesthetic, introspection, and interpersonal relationships. Theory of multiple intelligences, a student will be able to learn the material well if the material is delivered in accordance with the intelligence that is in accordance with the intelligence that stands out in the student (Wijaya \& Sudarmin, 2016). Multiple theory intelligence can actually improve activities and students' enjoyment of physics subjects because it turns out that the methods of studying physics are applied interesting and very fun with the intelligence they have (Septiana \& Ikhsan, 2017). Intelligence is more related to the capacity to solve problems and carve products in contextual and naturalistic contexts (Armstrong, 2009). This is in line with the research results of Asriani, et al, (2018) which states that the multiple intelligences approach through a problembased learning model can help students to connect prior knowledge with the new knowledge learned, as well as assist students in finding their own physics concepts. Therefore, everyone can develop this intelligence to an adequate level of mastery in his or her life. This intelligence often works together in complex and interrelated ways. The use of teaching techniques based on Multiple Intelligences Theory will have an impact on a significant increase in learning outcomes (Stanciu, et al., 2011).

One of them is logical-mathematical intelligence. Logical-mathematical intelligence is a combination of numeracy skills and logical abilities. Counting ability is a person's ability in matters relating to calculations, especially basic mathematical operations, while logical ability is a way to think about something rationally or based on reality (Fauziah, et al., 2015). According to Asriani, et al, (2018), not all students have a prominent or dominant logical and mathematical intelligence. Students with low logical and mathematical skills will inevitably have difficulty in learning. This causes students to be unable to solve problems. Differences in students' cognitive abilities require multiple intelligences methods to be able to follow problembased grammar learning according to their respective ability levels to achieve learning goals.

Based on the results of observations at SMAN 2 Mataram, teaching and learning activities are usually dominated by providing as much information as 
possible, without providing opportunities for students to connect the material learned with the knowledge used. This is because the time for online learning is limited and teachers are required to lead all students to achieve the goal of mastering the material. As a result, students are unable to develop their knowledge and influence compound intelligence. If this is noticed, students will be more receptive to the material taught. Therefore, through the application of problem-based learning models using a multiple intelligence approach, students are expected to learn more actively so as to improve their ability to solve problems.

\section{Method}

The type of research used in this research is research and development. The development model used in the study was the 4D (Defined, Designed, Developed, and Disseminated) model by Thiagarajan. Products to be developed are syllabus, lesson plan, student worksheet, logical-mathematical test instruments, and problem-solving ability test instruments.

The development of this learning media product through four stages, namely Defining stage, this stage is the initial stage of research aimed at getting information about problems in schools. The method used at this stage is through interview and observation sheets. Designing stage, the goal of this stage is to prepare an initial draft of the learning device. Developing stage, the objective of this stage is to produce a syllabus, lesson plan, student worksheet, logical-mathematical test instrument, and revised problem-solving capability test instrument based on comments, suggestions, and assessments from expert validators. The dissemination stage is the end of this stage of development research. The purpose of this stage is the dissemination of this development and research products.

To get data on the effectiveness of increasing students' multiple intelligences and problem-solving abilities, it can be determined using the Gain Standard with the following equation:

$$
\text { Std }<g>=\frac{\bar{X}_{\text {after }}-\bar{X}_{\text {before }}}{\bar{X}_{\text {max }}-\bar{X}_{\text {before }}}
$$

Where

$\bar{X}_{\text {after }}$ : post-test score

$\bar{X}_{\text {before }}:$ pre-test score

$\bar{X}_{\max }$ : maximum score 100

Based on the results obtained using the Gain Standard, the categories of students' multiple intelligences and problem-solving abilities are grouped according to Table 1.
Table 1. Interpretation of N-Gain Index

\begin{tabular}{ll}
\hline N-Gain Score $(\mathrm{g})$ & Category \\
\hline $0.70<\mathrm{g}<1.00$ & High \\
$0.30<\mathrm{g}<0.70$ & Medium \\
$0.0<\mathrm{g}<0.30$ & Low \\
$\mathrm{g}=0.00$ & Permanent \\
$-1.00<\mathrm{g}<0.00$ & There is a decrease
\end{tabular}

(Sundayana, 2016).

\section{Result and Discussion}

In the Define stage, there are three activities carried out, namely preliminary analysis, information obtained from interviews with one of the physics teachers at SMAN 2 Mataram that online learning carried out during the Covid-19 pandemic added to problems in the implementation of teaching and learning activities, for example, students rarely collect assignments and there is no network (internet quota) to carry out learning. Teaching and learning activities during this pandemic were carried out through the WhatsApp application, zoom meeting and google meet, but not many students took part in learning through google meet due to limited quota. Submission of material in online learning is carried out in the form of learning videos and providing material through the class WhatsApp group. During online learning, learning time is reduced so that teachers cannot fulfill a load of teaching hours as they should. The results of the task analysis are a collection of procedures to determine the contents of teaching material in outline based on Basic Competencies by the 2013 revised Curriculum on elasticity and Hooke's law materials.

Furthermore, the design stage is the stage of designing the initial draft of the learning device used in the Elasticity and Hooke's Law material. Learning tools based on problem-based learning models using multiple intelligences approaches and data collection instruments are then validated by expert validators and practitioner validators. The products produced at this stage are the problem-based learning model-based syllabus modifies the existing syllabus in the revised 2013 Curriculum. This syllabus serves as the basis for the preparation of the lesson plans, which contains Core Competencies, Basic Competencies, indicators of competency achievement, subject matter, learning activities, forms of assessment used, allocation of learning time, and learning resources. The Learning Process Plan based on a problem-based learning model using a multiple intelligences approach contains a guide for teachers to teach, which includes a learning scenario. In the core learning activities, the appropriate syntax is applied to the problem-based learning model using the multiple intelligences approach, namely: student orientation to problems, organizing students, guiding 
individual and group investigations, developing and presenting work, as well as analyzing and evaluating problem-solving processes.

The development stage is the stage to produce development products which are carried out through pre-test and post-test seen from the increase in student learning outcomes based on the average value of pretest and posttest, then analyzed using the N-Gain equation. The results can be seen in Tables 2 and 3 .

Table 2. Improving Students' Problem-Solving Ability.

\begin{tabular}{llll}
\hline$\overline{\mathrm{X}}$ pre test & $\overline{\mathrm{X}}$ post test & N-Gain & Category \\
\hline 22.26 & 66.78 & 0.57 & Medium \\
\hline
\end{tabular}

Table 3. Students' Mathematical Logical Improvement

\begin{tabular}{llll}
\hline$\overline{\mathrm{X}}$ pre test & $\overline{\mathrm{X}}$ post test & N-Gain & Category \\
\hline 6.25 & 64.97 & 0.63 & Medium \\
\hline
\end{tabular}

Tables 2. and 3. above show an increase in problem-solving and logical-mathematical abilities for students of class XI IPA 5 into the medium category with $\mathrm{N}$-Gain values of 0.57 and 0.63 . Based on the results of increasing problem-solving abilities and mathematical logic, as for finding out the achievement of the highest increase in problem-solving and logical-mathematical ability indicators, the following researchers describe the results of the N-Gain test from the component indicators of problem-solving and logical-mathematical abilities which can be seen in Tables 4 and 5 .

Table 4. Analysis of Problem-Solving Ability Class XI IPA 5

\begin{tabular}{lcccc}
\hline Indicator & $\begin{array}{c}\overline{\mathrm{X}} \\
\text { pre }\end{array}$ & $\begin{array}{c}\overline{\mathrm{X}} \\
\text { post }\end{array}$ & N-Gain & Category \\
\hline $\begin{array}{l}\text { Recognize } \\
\text { problems }\end{array}$ & 0.81 & 2.04 & 0.56 & Medium \\
Plan a strategy & 0.60 & 1.97 & 0.57 & Medium \\
$\begin{array}{l}\text { Implementing a } \\
\text { strategy }\end{array}$ & 0.63 & 2.02 & 0.59 & Medium \\
$\begin{array}{l}\text { Evaluating } \\
\text { Solutions }\end{array}$ & 0.64 & 1.99 & 0.57 & Medium \\
\hline
\end{tabular}

Table 5. Analysis of mathematical logical ability class XI IPA

\begin{tabular}{lllll}
\hline Indicator & $\overline{\mathbf{X}}$ & $\overline{\mathbf{X}}$ & N-Gain & Category \\
\hline pre & post & & \\
\hline $\begin{array}{l}\text { Count } \\
\text { Understanding }\end{array}$ & 0.13 & 1.38 & 0.44 & Medium \\
$\begin{array}{l}\text { relationship } \\
\text { patterns }\end{array}$ & 0.14 & 1.17 & 0.36 & Medium \\
Troubleshooting & 0.10 & 1.35 & 0.43 & Medium \\
\hline
\end{tabular}

Based on Table 4. on average there was an increase in the problem-solving ability of students in class XI IPA 5. The indicator that experienced the highest increase compared to other indicators was implementing a strategy of 0.59 in the medium category. This indicates that there is an increase in the problemsolving ability of students, although it is not too significant.

This is also supported by research conducted by Hastuti, et al, (2016) that the problem-based learning model can improve students' problem-solving abilities. In line with research (Astika, 2020) says that there is a significant increase in students' physics problemsolving abilities before and after being taught using the problem-based learning model.

In addition, research (Hasanah, et al., 2017) proves that the problem-based learning model based on multiple intelligences has increased significantly. In addition, the problem-based learning approach based on multiple intelligences can provide an increase in students' mathematical problem-solving abilities. This research was also conducted by (Asriani, et al., 2018) stating that the multiple intelligences approach through a problem-based learning model affects the physical problem-solving abilities of students in class X SMAN 2 Mataram in the 2017/2018 academic year. This shows that with the problem-based learning model, students can develop an understanding of concepts, the ability of a procedure, a way of thinking by providing related problems so that they understand the problem setting and can find out the next steps that must be taken through discussion. As a result of the discussion, students will become more skilled at using ideas and techniques that result in the experience of the problems they face (Saufi \& Royani, 2016).

Then based on Table 5, which shows that an increase of 0.63 . The highest increase occurred in the calculating indicator of 0.44 while the indicator of understanding relationship patterns and solving problems increased by 0.36 and 0.43 . So, it can be said that there is an increase in the problem solving and logical mathematical abilities of students, although it is not too significant. These results are relevant to Usman's research (2019) which revealed a weak positive relationship between logical-mathematical intelligence and physics problem-solving abilities of high school students.

Logical-mathematical intelligence will excel in the group of students who answer questions on types of math-diagram images, verbal diagrams, pictures, and verbal-mathematical pictures (Suminar, et al., 2013). Results like this with research by Faishol, et al., (2013) and Aripin, et al., 2021 state that problem-based learning can improve problem-solving abilities and students' logistical abilities.

In solving problems, three abilities are needed, namely the ability to interpret representations, apply strategies, and the ability to determine solutions to these 
problems. In interpreting someone obtains information from the representation provided and then generalizes to determine the solution to the problem. So that it can ensure that the main key to determining the solution to the problem is that students interpret the presentation presented.

\section{Conclusion}

Based on the results of the research and discussion above it can be concluded that the learning device of a problem-based learning model with an effective multiple intelligences approach is used to improve the physics problem-solving skills of learners.

\section{Acknowledgments}

Thanks to the Dean of FKIP, Head of the PMIPA Department, and Head of the Physics Education Study Program, and all parties so that this article can be carried out properly.

\section{References}

Armstrong, T. (2009). Multiple Intelligences in The Class Room 3rd Edition. USA: ASCD.

Aripin, W. A., Sahidu, H., \& Makhrus, M. (2021). Efektivitas Perangkat Pembelajaran Fisika Berbasis Model Problem Based Learning untuk Meningkatkan Kemampuan Pemecahan Masalah dan Kemampuan Berpikir Kritis Peserta Didik. Jurnal Penelitian dan Pembelajaran Fisika Indonesia, 3(1), $\quad$ https://doi.org/10.29303/ippfi.v3i1.120 [Indonesian]

Asmuni, A. (2020). Problematika Pembelajaran Daring di Masa Pandemi Covid-19 dan Solusi Pemecahannya. Jurnal Paedagogy, 7(4), 281-288. https://doi.org/10.33394/jp.v7i4.2941

Asriani, R., Hikmawati, H., \& Wahyudi, W. (2018). Pengaruh Pendekatan Multiple Intelligences Terhadap Kemampuan Pemecahan Masalah Fisika Siswa. Prisma Sains : Jurnal Pengkajian Ilmu dan Pembelajaran Matematika nan IPA IKIP Mataram, 6(2), 77-85. https://doi.org/10.33394/jps.v6i2.1082 [Indonesian]

Astika, Desi. (2020). Penerapan Model Pembelajaran Problem Based Learning (PBL) Untuk Meningkatkan Kemampuan Pemecahan Masalah Fisika Peserta Didik Kelas XI IPA SMA Negeri 3 Bulukumba. Retrieved from, https://digilibadmin.unismuh.ac.id/upload/11 039-Full_Text.pdf. [Indonesian]

Celik, P., Onder, F., \& Silay, I. (2011). The effects of problem-based learning on the students' success in hysics course. Procedia - Social and Behavioral Sciences, 28, 656-660. https://doi.org/10.1016/j.sbspro.2011.11.124

Faishol, A., Suyitno, H., \& Hindarto, N. (2013). Pengembangan Perangkat Pembelajaran Model Problem Based Learning Untuk Meningkatkan Kemampuan Berpikir Kreatif. Journal of Primary Education, 2(2), 115-119. https://doi.org/10.15294/jpe.v2i2.2985

[Indonesian]

Fauziah, K. R., Nurhayati, \& Arsyad, M. (2015). Analisis Hubungan Antara Kecerdasan Logis-Matematis Dengan Hasil Belajar Fisika Peserta Didik Kelas Xi Ipa Sma Negeri Di Kabupaten Jeneponto. Jurnal Sains Dan Pendidikan Fisika, 11(3), 239-244. https://doi.org/10.35580/jspf.v11i3.1740 [Indonesian]

Gunada, I. W., Sahidu, H., \& Sutrio, S. (2015). Pengembangan Perangkat Pembelajaran Fisika Berbasis Masalah untuk Meningkatkan Hasil Belajar dan Sikap Ilmiah Mahasiswa. Jurnal Pendidikan Fisika dan Teknologi, 1(1), 38-41. http://dx.doi.org/10.29303/jpft.v1i1.233

[Indonesian]

Hardiyanto, H., Susilawati, S., \& Harjono, A. (2015). Pengaruh Model Pembelajaran Berbasis Masalah dan Ekspositori dengan Keterampilan Proses Sains Terhadap Hasil Belajar Fisika Siswa Kelas VIII MTsN 1 Mataram Tahun Ajaran 2014/2015. Jurnal Pendidikan Fisika Dan Teknologi, 1(4).249256. http://dx.doi.org/10.29303/ipft.v1i4.267 [Indonesian]

Hasanah, L. A., Sudin, A., \& Maulana, M. (2017). Pengaruh Pendekatan Problem-Based Learning (Pbl) Berbasis Multiple Intelligences Terhadap Kemampuan Pemecahan Masalah Matematis Siswa Pada Materi Pecahan Kelas IV Semester 2. Jurnal Pena Ilmiah, 2(1), 1141-1150. https://doi.org/10.17509/jpi.v2i1.11263

[Indonesian]

Hastuti, A., Sahidu, H., \& Gunawan, G. (2016). Pengaruh Model PBL Berbantuan Media Virtual Tehadap Kemampuan Pemecahan Masalah Fisika. Jurnal Pendidikan Fisika Dan Teknologi, 2(3).129-135.

http://dx.doi.org/10.29303/jpft.v2i3.297

[Indonesian]

Kamsari, \& Winarso, W. (2018). Implikasi Tingkat Kecerdasan Logika Matematika Siswa terhadap Pemecahan Permasalahan Matematika. Jurnal Pendidikan Sain dan Matematika, 6(1) 44-52. https://doi.org/10.23971/eds.v6i1.785

[Indonesian]

Lestari, S. I., Budiyono, \& Slamet, I. (2015). Eksperimentasi Model Pembelajaran Problem 
Based Learning ( Pbl ), Discovery Learning ( Dl ), Dan Problem Possing ( Pp ) Ditinjau Dari Kecerdasan Majemuk Siswa Pada Materi Kubus Dan Balok Smp Negeri Kabupaten Demak. Jurnal Pembelajaran Matematika, 3(8), 811-823. https://jurnal.uns.ac.id/ipm/article/view/1077 2[ [ndonesian]

Pitriah, P., Sutrio, S., \& Taufik, M. (2018). Pengaruh Model Pembelajaran Berbasis Masalah Berbantuan Alat Peraga Tiga Dimensi Terhadap Hasil Belajar Fisika Peserta didik Tahun Pelajaran 2017/2018. Jurnal Pendidikan Fisika Dan Teknologi, 4(2). $\quad$ https://doi.org/10.29303/ipft.v4i2.566 [Indonesian]

Ramdoniati, N., Muntari, \& Hadisaputra,S. (2019). Pengembangan Bahan Ajar Kimia Berbasis Problem Based Learning Untuk Meningkatkan Kemampuan Metakognisi. Jurnal Penelitian Pendidikan IPA, 5(1), 27-33. http://dx.doi.org/10.29303/ippipa.v5i1.148 [Indonesian]

Saufi, M., \& Royani, M. (2016). Mengembangkan Kecerdasan Interpersonal dan Kepercayaan Diri Siswa Melalui Pembelajaran PBL. Mact Didactic:Jurnal Pendidikan Matematika, 2(2), 106116. https://doi.org/10.33654/math.v2i2.35 [Indonesian]

Septiana, K. G., \& Ikhsan, J. (2017). Pengaruh Penerapan Multiple Intelligences dengan Model PBL Terhadap Pemahaman Konsep dan Kemampuan Berpikir Kreatif. Jurnal Edukasi Matematika dan Sains, 5(1), 44-52. http://doi.org/10.25273/jems.v5i1.1785 [Indonesian]

Selçuk, G. S., \& Çalişkan, S. (2010). A Small-Scale Study Comparing the Impacts of Problem-Based Learning and Traditional Methods on Student Satisfaction in The Introductory Physics Course. Procedia - Social and Behavioral Sciences, 2(2), 809813.

https://doi.org/10.1016/j.sbspro.2010.03.108

Stanciu, D., Orban, I., \& Bocos, M. (2021) Applying the Multiple Intelligences Theory into Pedagogical Practice. Lessons from the Romanian Primary Education System, Procedia Social and Behavioral Sciences, 11(1), 92-96. https://doi.org/10.1016/j.sbspro.2011.01.040

Suminar, I., Siahaan, P. \& Sari Mustika, I. (2013). Peningkatan Hasil Belajar Kognitif Siswa SMP Melalui Pembelajaran Dengan Multi Representasi Dikaitkan Dengan Kecerdasan Majemuk Dalam Pembelajaran IPA Fisika. Jurnal Wahana Pendidikan Fisika, 1(1), 99-110. https://doi.org/10.17509/wapfi.v1i1.4899

[Indonesian]
Supriadi, Wildan, \& Laksmiwati, D. 2020. Implementasi Model Pembelajaran Berbasis Masalah dan Pengaruhnya terhadap Perkembangan Karakter Mahasiswa. Jurnal Penelitian Pendidikan IPA, 6(1),63-68.

https://doi.org/10.1016/i.sbspro.2011.01.040 [Indonesian]

Sulaiman, F. (2010). Students' Perceptions of Implementing Problem-Based Learning in a Physics Course. Procedia - Social and Behavioral Sciences, $\quad 7(\mathrm{C}), \quad 355-362$. https://doi.org/10.1016/j.sbspro.2010.10.048.

Sundayana, R. (2016). Statistika Penelitian Pendidikan. Bandung: Alfabeta. [Indonesian]

Usman, (2019) The Relationship of Logicalmathematical Intelligence and Learning Motivation with Problem Solving Skill of Class XI Students of SMA Negeri 14 Sinjai. Sainsmat: Jurnal Ilmiah Ilmu Pengetahuan Alam, 8(1), 60-69. http://dx.doi.org/10.35580/sainsmat811018920 $\underline{19}$.

Venisari, R., Gunawan, G., \& Sutrio, S. (2017). Penerapan Metode Mind Mapping pada Model Direct Instruction untuk Meningkatkan Kemampuan Pemecahan Masalah Fisika Siswa SMPN 16 Mataram. Jurnal Pendidikan Fisika Dan Teknologi, 1(3). https://doi.org/10.29303/ipft.v1i3.258 [Indonesian]

Wahyuni, S., Rahayu, Y., S., \& Indana, S. 2020. Development of Problem-Based Learning Student Worksheets to Facilitate Students' Problem-Solving Skills. Jurnal Penelitian Pendidikan IPA, 6(2), 162-165. https://doi.org/10.29303/jppipa.v6i2.427.

Wijaya, K. H., \& Sudarmin. (2016). Kemampuan Pemecahan Masalah Matematik Siswa Kelas VIII Berdasarkan Multiple Intelligence Pada Setting PBL. Unnes Journal of Mathematics Education Research, 5(2), 114-131. https://journal.unnes.ac.id/sju/index.php/ujm er/article/view/12928 [Indonesian]

Wulandari, E., F., \& Shofiyah, N. (2018) Model Problem Based Learning (PBL) dalam Melatih Scientific Reasoning Siswa. Jurnal Penelitian Pendidikan IPA. 3(1):33-38. https://journal.unesa.ac.id/index.php/jppipa/a rticle/view/3150/1984 [Indonesian] 